\title{
Challenges of ecosystem restoration in Louisiana - availability of sediment and its management
}

\author{
SYED M. KHALIL \& ANGELINA M. FREEMAN \\ Coastal Protection and Restoration Authority of Louisiana, PO Box 44027, Baton Rouge, Louisiana 70804-4027, USA \\ syed.khalil@la.gov
}

\begin{abstract}
Human intervention has impaired the Mississippi River's ability to deliver sediment to its delta wetlands, and as a consequence acute land loss in coastal Louisiana has resulted in an unprecedented ecocatastrophe. To mitigate this degradation, an unparalleled restoration effort is underway. For this effort to be successful and sustainable, various sediment input mechanisms must be integrated, including: building appropriate sediment-diversions; beneficially using the millions of cubic metres of sediment dredged annually from navigational channels; harvesting deposits of sand and suitable sediment from the river and offshore; and related sediment management activities that are compatible with other uses of the river. A comprehensive sediment management plan has been developed to identify and delineate potential sediment sources for restoration, and to provide a framework for managing sediment resources wisely, cost effectively, and in a systematic manner. The Louisiana Sediment Management Plan provides regional strategies for improved comprehensive management of Louisiana's limited sediment resources.
\end{abstract}

Key words sediment management; coastal land loss; sand resources; Louisiana Coastal Master Plan; river diversion; Mississippi River Delta; deltaic plain

\section{INTRODUCTION}

The Mississippi River Delta formed over the last $\sim 7000$ years as the Mississippi River deposited sand, silt, and clay into its receiving basin, the Gulf of Mexico. Similar to most of the world's large deltas, the Mississippi River Delta began to form when sea level rise decelerated after the last glacial maximum c.20 000 years ago (Stanley \& Warne, 1994). The Mississippi River drains approximately $40 \%$ of the United States $\left(3.4 \times 10^{6} \mathrm{~km}^{2}\right)$, and presently discharges an average of $15360 \mathrm{~m}^{3} / \mathrm{s}$ of freshwater annually. Historically, the Mississippi River carried an estimated sediment load of 400 million metric tons (MMT) per year before dams, levees, locks, meander cutoffs, and other engineering structures, as well as improved soil conservation for croplands and forests in the watershed, were put in place in modern times (Kesel, 2003; Meade \& Moody, 2010). Currently the sediment load has been reduced by large-scale human activities to approximately 145 MMT (Blum \& Roberts, 2009; Meade \& Moody, 2010). The reduction in sediment supply, and the separation of the delta from the river caused by levees, have been major factors in the $5000 \mathrm{~km}^{2}$ of land lost in coastal Louisiana since the 1930s (Barras et al., 2003). Ecosystem sustainability has thereby been compromised (Day et al., 2007), a phenomenon seen in highly engineered deltaic systems worldwide (Zalasiewicz et al., 2010). Oil and gas extraction and infrastructure, invasive species, sea-level rise and storms also contribute to land loss. Subsidence increases the vulnerability of deltas, with rapidly deposited sediments that compact and de-water, adding to relative sea level rise. Coastal Louisiana experiences some of the highest subsidence rates worldwide, making the Mississippi River Delta one of the first areas to experience the effects of global sea-level rise.

Over the next 50 years, coastal land loss rates in Louisiana are projected by Barras et al. (2003) at $26.7 \mathrm{~km}^{2}$ per year, and Louisiana's Master Plan evaluated a less optimistic scenario with an average annual loss rate of $90.7 \mathrm{~km}^{2}$ over 50 years (CPRA, 2012). The Mississippi River Delta is the most ecologically productive ecosystem of its size in North America (Day et al., 2014). The wetlands, estuaries, and barrier islands making up the delta provide great economic value, serving as nursery grounds for both sport and commercial fisheries, providing wildlife habitat, attenuating storm effects, supporting the largest port by tonnage in the world, and containing energy reserves. With the loss of coastal wetlands comes a diminishment in the ecosystem services provided (Batker et al., 2010; Batker et al., 2014). 
The predicted deterioration of ecologically productive coastal wetlands worldwide has led to numerous coastal restoration initiatives. A large-scale effort to restore the Mississippi River Delta is underway (Boesch, 1996, 2006; CPRA, 2012). An ambitious comprehensive Master Plan for coastal restoration and protection in Louisiana was developed by a team of scientists and engineers, using planning-level numerical modelling combined with public input, to select the most effective combination of restoration and flood protection measures (CPRA, 2012). The feasibility of the plan is predicated on the availability of sufficient volumes of sediment. Realizing the unprecedented nature of the degradation and the intended massive restoration effort, optimizing utilization of every grain of sediment is recommended. Ironically, on one hand it is realized and understood that the present situation is an outcome of lack of sediment input into the ecosystem, but on the other hand, a huge amount of sediment (approx. 145 MMT) debouching annually onto the continental slope of Gulf of Mexico is not harvested and utilized. Additionally about 20 million cubic metres (MCM) of sediment dredged during the maintenance dredging of navigation channels is disposed of non-beneficially every year (USACE, 2014).

Blum \& Roberts (2009) determined that, without sediment input to the delta, an additional $10000-13500 \mathrm{~km}^{2}$ of coastal Louisiana land will drown by 2100 due to subsidence and sea level rise. This will create a new accommodation space of about $12-16 \mathrm{~km}^{3}$, requiring about $18-24 \mathrm{BT}$ of sediment to fill. Morton et al. (2010) calculated that 2.9 billion cubic metres (BCM) of accommodation was created by land loss of approx. $4877 \mathrm{~km}^{2}$ from 1932 to 2010 . If this trend is projected forward, it is estimated that about 1.2 BCM of accommodation space will be created under a moderate scenario of relative sea level rise (RSLR) by a land loss of $\sim 1994 \mathrm{~km}^{2}$ between 2010 and 2060. The accommodation will be much higher, approx. 2.7 BCM, if a less optimistic scenario of RSLR is considered under which land loss during the same period of time (2010-2060) will be $\sim 4532 \mathrm{~km}^{2}$. These are first-order approximations. The amount of sediment needed to fill this accommodation space will be much more and will depend upon the cut to fill ratio which in turn depends upon the type of sediment. In order to manage sediment volume of such magnitude, the State of Louisiana has developed a framework for sediment management in the Louisiana Sediment Management Plan (LASMP) (Khalil et al., 2010). This paper describes the ongoing efforts in Louisiana to locate potential sand resources in offshore and riverine borrow sites, as well as efforts to capture and use fluvial sediment resources for restoration, and to manage these via dedicated dredging and beneficial use of dredged sediment in the near term and through planned sediment diversions in the long term. Coastal Louisiana is a sediment-starved system, and there is a need for hundreds of MCM of sediment for coastal Louisiana restoration (Khalil \& Finkl, 2009). Offshore sediment resources can supply a portion of the needed sediment volume. Even with the reduced current sediment load, the Mississippi River and its distributary, the Atchafalaya River, still contribute approximately $95 \%$ of all sediment entering the northern Gulf of Mexico (Fig. 1) (Milliman \& Syvitski, 1992; Anderson \& Fillon, 2004). In the face of rising sea levels and reduced river sediment supply, it is critical to optimize utilization of both offshore and fluvial sediment resources in the LASMP framework.

\section{PURPOSE AND GOALS}

The success of the coastal protection and restoration effort is dependent on identifying and optimizing the use of sufficient sediment resources. Sediment is a vital resource in this currently sediment-limited deltaic setting, with sand needed for restoring barrier islands, and a mix of sand, silt and clay needed for creating and nourishing wetlands. A comprehensive LASMP framework has been developed in Louisiana for comprehensive management of sand, silt, and clay sediments. 




Fig. 1 Map of coastal Louisiana showing locations of various offshore sand sources, barrier island restoration, and marsh creation sites.

\section{MANAGING SEDIMENT FOR COASTAL PROTECTION AND RESTORATION}

\section{Louisiana sediment management plan (LASMP)}

To re-establish a sustainable coastal ecosystem, large quantities of various types of sediment both from renewable riverine and offshore sources are needed to mitigate erosion of wetlands. Therefore, a meaningful restoration program must include a comprehensive sediment management plan, and integrate various sediment input mechanisms, including: beneficially using the millions of cubic metres of sediment dredged annually from navigational channels; harvesting deposits of sand in the river and offshore; building appropriate sediment-diversions; and related sediment management activities that are compatible with other uses of the river. It is noted that LASMP is a comprehensive sediment management plan which not only identifies and inventories all proven and potential sediment resources, but is also a tool and opportunity to proactively identify and minimize conflicting uses for sediment such that more sediment could be made available efficiently and cost-effectively by proper management. It is emphasized that sediment management is paramount for the sustainable coastal protection and restoration of coastal Louisiana.

\section{Tools for implementing Louisiana's sediment management plan}

LASMP conceptualizes systematic planning and better coordination of essential components of the restoration and protection effort. The Delta Sand Search Model (DSSM) and the Louisiana Sand Resources Database (LASARD) are two important tools for implementing this plan (Khalil et al., 2010). The DSSM aids in efficient, systematic and cost effective exploration for offshore sand in muddy deltaic environments as finding sands "... in coastal Louisiana are much more complicated due to inherent lateral and vertical variability of sediment facies associated with a complex deltaic environmental regime" (Finkl \& Khalil, 2005). This model is also applicable for exploring sand in the fluvial environment. Such exploration surveys not only generate huge amounts of geoscientific/geophysical data but also are benefitted by historical data gathered by past surveys. In order to manage the large geological, geophysical, and geotechnical data pertaining to sediment resources and restoration planning, LASARD was developed. This database has been expanded to include hydrological and other datasets related to restoration efforts. Historical and current data are 
archived, and this centralized, publically available dataset can be queried for planning and executing protection and restoration projects (Khalil et al., 2007).

\section{Sediment resources in Louisiana}

Offshore/nearshore sediment resources Sand is needed for barrier island restoration and beach and dune nourishment. In Louisiana's predominantly muddy coast, sand resources are limited to offshore shoals and buried relict palaeo-stream channels (Khalil \& Finkl, 2009). Sabine Bank, the Tiger and Trinity Shoal Complex, Ship Shoal Complex, and St. Bernard Shoal (Fig. 1) are major prominent sand bodies with significant reserves of sand. However, the "dredgeable" quantity of sand is drastically reduced due to excessive safety buffer requirements by regulatory agencies for subsea infrastructures placed by petroleum industries, and also environmental and cultural concerns over dredging in these shoals.

The Louisiana Geological Survey in collaboration with the US Geological Survey (USGS) investigated the distribution and character of sand-rich sediments that make up the shallow stratigraphy (approx. top $15 \mathrm{~m}$ ) of the continental shelf. In a range of depositional systems, 55 nearshore, sand-rich deposits were identified within modern and abandoned deltaic sediments, including: spit platforms; delta sheet sands; ebb- and flood-tidal deltas; distributary mouth bars; distributary-channel fills; and inner-shelf shoals. This reconnaissance survey was followed by a USGS study (Kindinger et al., 2001) that identified other types of sandy deposits that contributed to shelf sand resources. The initial reserve estimates on the basis of these regional surveys indicated a potential for hundreds of cubic metres of sand. As anticipated, these reconnaissance volume estimates were refined when detailed surveys were conducted (e.g. Finkl et al., 2003) showing smaller volumes of potentially usable sand resources. It may be added here that these nearshore sand deposits are mostly located in buried palaeochannels and bar deposits. Most of these deposits are covered by muddy deltaic overburden of mostly mixed silt and clay and are limited in volume.

A surficial sediment distribution map was developed from existing geophysical and geotechnical data for offshore Louisiana (Fig. 2). This sediment map is the first instance of a firstorder assessment of sediment volumes, with a total volume of $\sim 75 \mathrm{BCM}$, and a dredgeable estimated volume of $\sim 55.3 \mathrm{BCM}$ (Fig. 2). The classification and delineation of the surficial extent of sediment types are based on limited data, over a limited extent and depth. Therefore, the boundaries and quantification of sediment is a first-order approximation and will be refined once more data become available. These offshore sediment volumes are finite sediment resources and are not renewable like fluvial sediments.

Inshore/estuarine/bays and lakes Finer-grained sediments found in estuarine bay and lake settings are effective for marsh creation and nourishment projects. Given the proximity to restoration projects, it can be cost-effective and efficient if the sediments are dredged from nearby bays, lakes, or estuaries. To evaluate the impact of dredging significant quantities of sediment from bays and estuaries for that purpose, the Coastal Protection and Restoration Authority (CPRA) has undertaken a Borrow Area Management and Monitoring (BAMM) program which is also an integral component of LASMP and aids in optimizing utilization of borrow areas.

Fluvial sediment resources Current annual average sediment discharge of the Mississippi River is approx. 145 MMT. Riverine sediment resources can supply a portion of the needed sediment volume; however the riverine sediment supply is not sufficient to restore the entire coastal plain to its former footprint in the face of rising sea levels and reduced sediment supply (Blum \& Roberts, 2009). Fluvial sand sources in channel and point-bar deposits are an attractive source for wetlands/barrier island restoration (Finkl et al., 2005), and the sources can be close to a project area. Sand bars located in hydro-geomorphological settings (river meander point bars) have the added advantage of being naturally replenished by fluvial deposition of traction bedload. Due to the thickness of these river sands, large volumes are potentially available for coastal restoration (Finkl et al., 2006). A first-order assessment of Mississippi River sand volumes was developed, with a total sand volume from river mile 70 to Head of Passes (Fig. 1) of $0.5 \mathrm{BCM}$ with $0.41 \mathrm{BCM}$ 


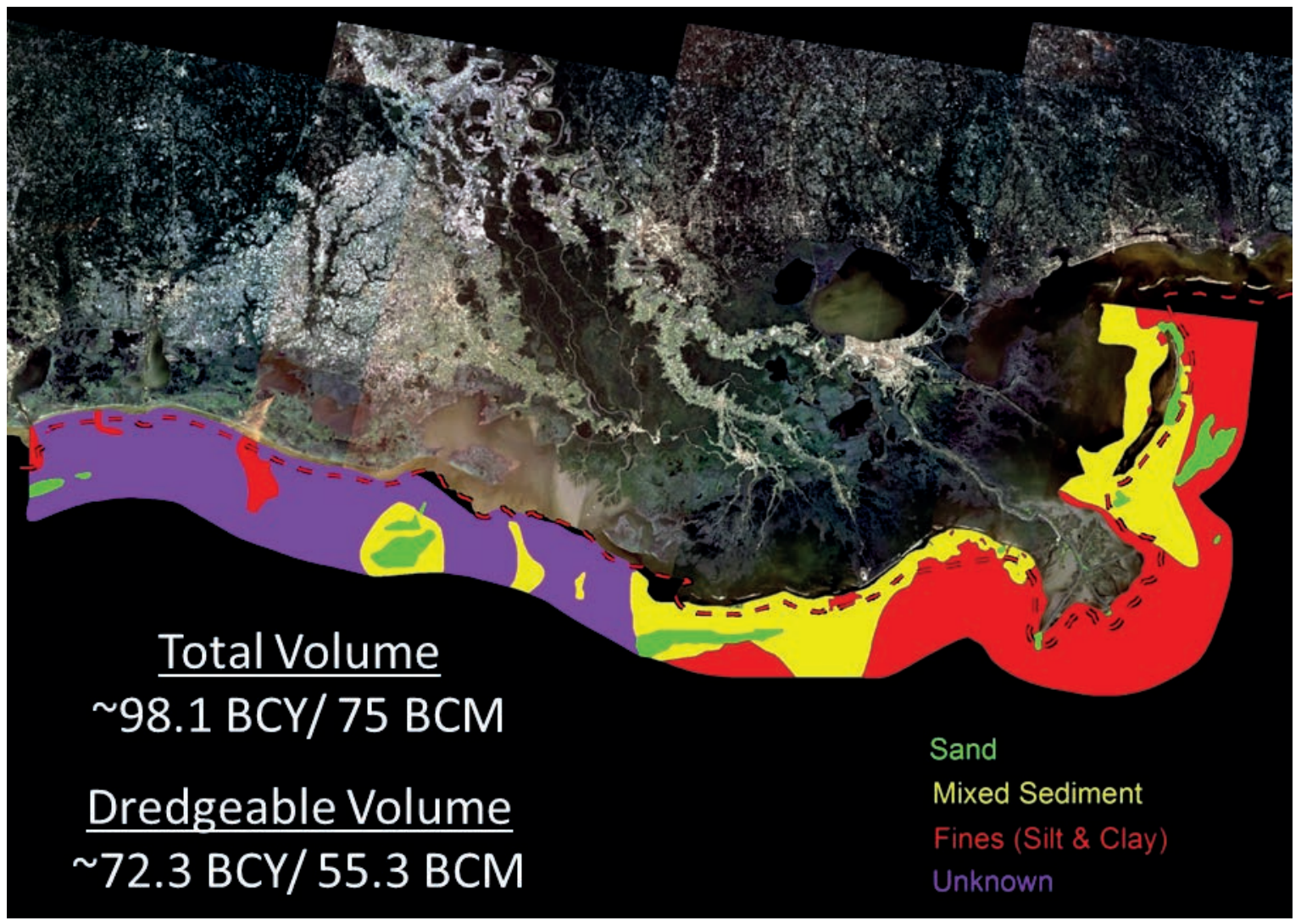

Fig. 2 First-order assessment of offshore Louisiana surficial sediment distribution and volume.

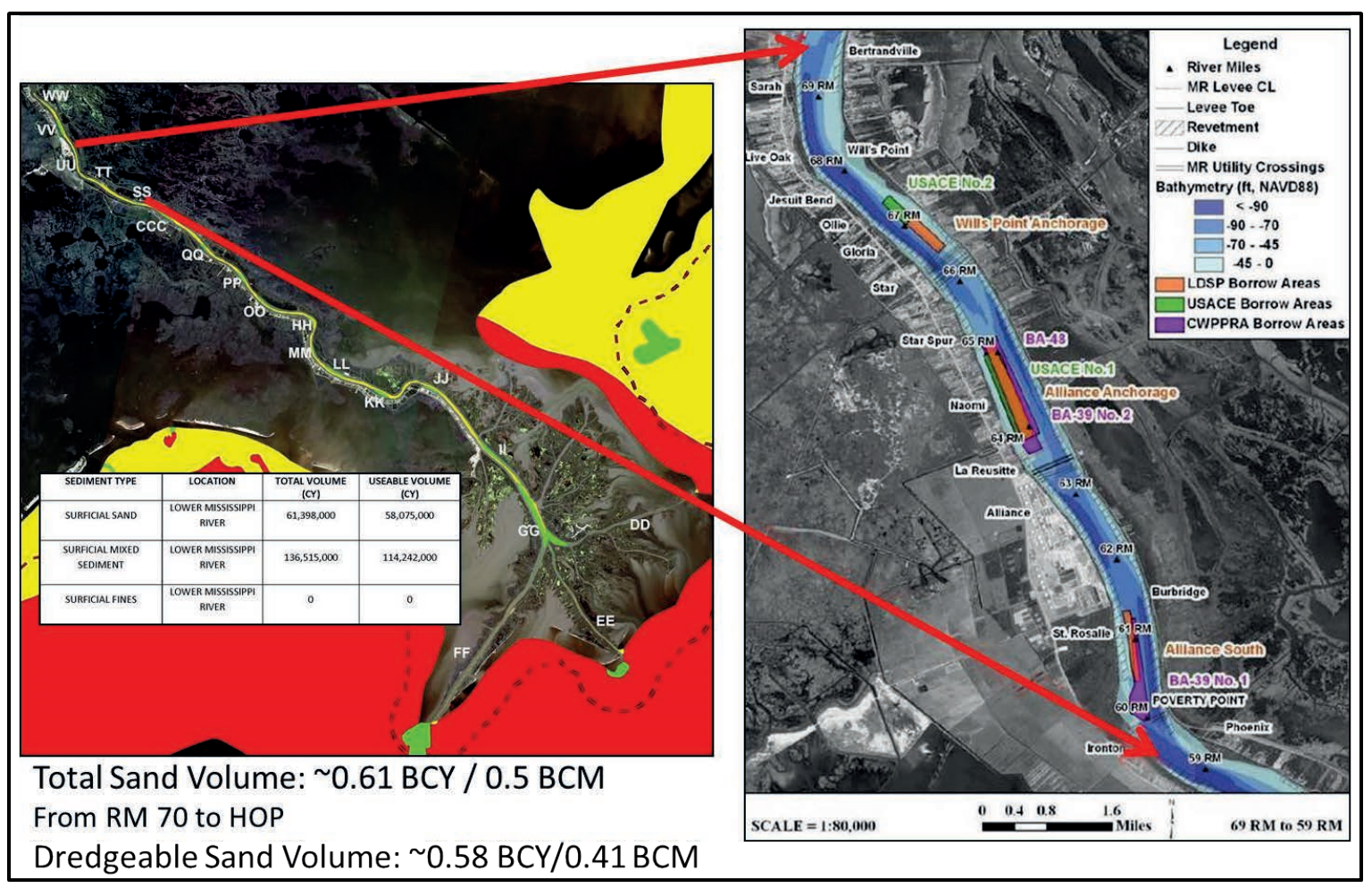

Fig. 3 First-order assessment of Lower Mississippi River sand and mixed sediment volume. 
of this assessed to be dredgeable (Fig. 3). The classification and delineation of the surficial extent of sediment types are based on limited data; therefore the sediment volumes are at best a firstorder approximation.

\section{DISCUSSION}

Fluvial or riverine sediment sources are important and critical for restoration for several reasons, most importantly they are renewable. These sediments could be captured/utilized for restoration in many ways. In the near term, sand/sediment from the river could be utilized to create marsh platform/barrier islands via dedicated dredging as has been done recently for a few projects (e.g. Bayou DuPont Marsh Creation, Scofield Barrier Island Restoration, and Shell Barrier Island restoration (Fig. 1)) and will be utilized in the near future for marsh creation via the Long Distance Sediment Pipeline Project. The US Army Corps of Engineers (USACE) New Orleans District dredged an annual average (1996-2012) of approx. 60 MCM of sediment from the Lower Mississippi River to maintain the navigation channels in coastal Louisiana (Creef, 2014, pers. comm.). Approximately half of the sediment dredged is deemed suitable and available for beneficial use, but only an average of $12 \mathrm{MCM}$ per year is used beneficially. Still about $20 \mathrm{MCM}$ of sediment which is available and suitable for beneficial use every year, is disposed of (Creef, 2014, pers. comm). The Federal Standard is often quoted as one of the reasons for the inability of the USACE to use these sediments more beneficially (USEPA, 2007). However, the wetland loss is continuing with an average rate of $43 \mathrm{~km}^{2}$ annually (Couvillion et al., 2011). If this loss is to be mitigated by $0.3 \mathrm{~m}$ thick sediment with a cut to fill ratio of 1:2, about $18.8 \mathrm{MCM}$ of sediment will be needed which is the same amount of sediment USACE disposes non-beneficially every year. Obviously it is critical to find ways in the near term to utilize these MCMs of sediment from maintenance dredging which are being disposed of annually. However, with increasing cost, these strategies will become cost-prohibitive. Restoring the delta must include tools that restore or imitate natural deltaic land building processes. Reconnecting the river through diversions that maximize sediment capture is one such tool. The Mississippi River was engineered mainly for flood control and navigation purposes. But now the Mississippi River must play a multifaceted role where it is a source of sediment and a driver that not only sustains the regional wetland and coastal ecosystems but also serves other vital purposes such as navigation, flood control, and water supply. To inform the siting and operation of diversions, lessons could be learned from the Atchafalaya River which is the main functioning distributary of the Mississippi River. The Atchafalaya River and hydrologic basin and the expanding deltas (Atchafalaya and Wax Lake deltas) are the only portion of Louisiana's coastal region where land mass is being created (Fig. 1).

The best, most effective and sustainable way is to infuse sediment into the degraded wetlands of Louisiana by re-establishing the natural deltaic process of reconnecting the river to the delta plain via sediment diversions. It is understood and appreciated that to be meaningful, the diversions should be sited high up in the estuary which will not only mimic natural delta building processes but will provide a receiving basin with higher sediment retention capacity which is crucial for land building process. An understanding of the Atchafalaya River basin water and sediment budgets is critical to the planning and engineering of diversions and other mechanisms to re-introduce riverine sediments into the Louisiana coastal zone from the main stem of the Mississippi River. CPRA has a current study entitled "Delta Development \& Coastal Marsh Accretion During Cold Front Passage \& Floods: Relevance to River Diversion" that is underway and is expected to improve our understanding of sediment retention in the delta and adjacent coastal environments, as well as the predicted responses of river diversions and where they should be placed to have the greatest positive impact. The State of Louisiana, in partnership with the USACE, is also currently undertaking a Mississippi River Hydrodynamic and Delta Management study to identify and evaluate a combination of large-scale management and restoration projects. The study covers the lower Mississippi River and surrounding deltaic region, and provides a modelling framework for management decisions to support a sustainable coastal ecosystem that allows for the coexistence of restoration, flood control, and navigation. 
The success of Louisiana's Coastal Master Plan restoration efforts depends greatly on locating, managing, and utilizing sediments in a cost-effective manner to build between 930 and $1280 \mathrm{~km}^{2}$ of land with an estimated cost of 50 billion dollars over the next 50 years (CPRA, 2012). To achieve coastal restoration effort of this magnitude, a strategy emphasizing an understanding of sediment dynamics (inputs, outputs, and movement) relative to available sediment resources and their proximity to restoration projects in the form of a Louisiana Sediment Availability and Allocation Program (LASAAP) is recommended. Sediment resource inventories (availability) and subsequent project allocations lend themselves to a GIS environment where a variety of sediment resource datasets can be spatially evaluated to ensure the most effective use of sediment for individual restoration sites. Traditionally, the matching of sediment sources and projects has been done manually. Development of a system/tool (LASAAP) to assist with matching sediment sources and sediment needs would improve the efficient use of limited sediment supplies. This program will take into consideration, component and factors like policy updates, infilling rates (reuse of borrow areas), transportation cost, dredging restrictions relative to infrastructure, environmental impacts, sediment characteristics, conflicting/competing uses, leveraging mobilization for multiple projects, permitting etc. This multi-scale planning approach would establish an acceptable level of confidence for determining where most compatible sediment sources (volume and grain size) are available for all planned restoration options.

\section{CONCLUSIONS}

The future landscape of coastal Louisiana depends upon the efficacy and success of restoration strategies recommended in the 2012 Master Plan adopted by the State. It is understood that for restoration projects, such as barrier island restoration or marsh platform creation, the majority of cost (90-95\%) is incurred in locating, dredging, transporting, and placing the sediment. With the steady rise in energy cost, the unit cost of placement per $\mathrm{m}^{3}$ of sand/sediment is increasing steadily. Therefore, for a sustainable ecosystem restoration and land building effort to mitigate for land loss, sediment diversions are the most viable solution in the long term. Managing the Lower Mississippi River is a great challenge due to its complex sediment-water dynamics and the multiple (and often competing) uses of its resources; however, restoring a more healthy sediment budget by reconnecting the river and coastal/littoral systems would re-establish more natural, landsustaining processes. Riverine and offshore/nearshore sediment resources must also be identified in the framework of the newly developed LASMP, and the available sediment resources used strategically to optimize restoration strategies with the aid of recommended Louisiana Sediment Availability and Allocation Program.

\section{REFERENCES}

Anderson, J. B. \& Fillon, R. H. (2004) Late Quaternary stratigraphic evolution of the northern Gulf of Mexico margin. Tulsa, Oklahoma: Society for Sedimentary Geology.

Barras, J., et al. (2003) Historical and predicted coastal Louisiana land changes: 1978-2050. US Geological Survey Open-File Report.

Batker, D., et al. (2014) The threats to the value of ecosystem goods and services. In: Perspectives on the restoration of the Mississippi Delta: the once and future delta, (ed. by J. W. Day, et al.). New York: Springer.

Batker, D., et al. (2010) Gaining ground: wetlands, hurricanes and the economy: the value of restoring the Mississippi River Delta, p. 101. Earth Economics.

Blum, M. D. \& Roberts, H. H. (2009) Drowning of the Mississippi Delta due to insufficient sediment supply and global sealevel rise. Nature Geoscience. 2, 488-491.

Boesch, D. (1996) Science and management in four U.S. coastal ecosytems dominated by land-ocean interactions. $J$ Coast Conserv. 2(2), 103-114.

Boesch, D. F. (2006) Scientific requirements for ecosystem-based management in the restoration of Chesapeake Bay and Coastal Louisiana. Ecological Engineering. 26(1), 6-26.

Couvillion, B. R., et al. (2011) Land Area Change in Coastal Louisiana from 1932 to 2010. US Geological Survey Scientific Investigations Map 3164, scale 1:265,000.

CPRA (2012) Louisiana's Comprehensive Master Plan for a Sustainable Coast, Coastal Protection and Restoration Authority, State of Louisiana. Available from: http://www.coastalmasterplan.louisiana.gov/ (March 1, 2013)

Creef, E. (2014, Personal communication).

Day, J., et al. (2014) Introduction: Perspectives on the restoration of the Mississippi Delta. In: Perspectives on the Restoration of the Mississippi Delta: The Once and Future Delta, (ed. by J. W. J. Day, et al.). New York: Springer. 
Day, J. W., et al. (2007) Restoration of the Mississippi Delta: Lessons from Hurricanes Katrina and Rita. Science. 315, 1679-1684.

Finkl, C.W., et al. (2003) Barataria/Plaquemines barrier shoreline restoration project: Geotechnical investigation and analysis. CPE Inc. Submitted to National Oceanic and Atmospheric Administration (NOAA) and Louisiana Department of Natural Resources, Boca Raton, Florida.

Finkl, C. W., et al. (2005) Geotechnical investigation for exploration of sand resources in the lower Mississippi River and South Pass, and exploration for sand via vibracoring in South Pelto Blocks 12 \& 13. CPE Inc. Report prepared for the Louisiana Department of Natural Resources, Baton Rouge, Louisiana.

Finkl, C. W. \& Khalil, S. M. (2005) Offshore exploration for sand sources: general guildelines and procedural strategies along deltaic coasts. Journal of Coastal Research.(Special Issue 44), 203-233.

Finkl, C. W., et al. (2006) Fluvial sand sources for barrier island restoration in Louisiana: Geotechnical investigations in the Mississippi River. Journal of Coastal Research. 22(4), 773-787.

Kesel, R. H. (2003) Human Modification to the Sediment Regime of the Lower Mississippi River Flood Plain. Geomorphology. 56(3-4), 325-334.

Khalil, S. M. \& Finkl, C. W. (2009) Regional sediment management strategies for coastal restoration in Louisiana, USA. Journal of Coastal Research (Special Issue 56), 1320-1324.

Khalil, S. M., et al. (2007) Restoration-quality sand from Ship Shoal, Louisana; geotechnical investigation for sand on a drowned barrier island. Proceedings of Coastal Sediments '07, 685-698. New Orleans, Louisiana.

Khalil, S. M., et al. (2010) New approaches to sediment management on the inner continetnal shelf offshore coastal Louisiana. Journal of Coastal Research. 26(4), 591-604.

Kindinger, J., et al. (2001) Sand resources, regional Geology, and coastal processes for the restoration of the Barataria barrier shoreline. US Geological Survey, Open File Report 01-384. New Orleans, LA: US Army Corps of Engineers.

Meade, R. H. \& Moody, J. A. (2010) Causes for the decline of suspended-sediment discharge in the Mississippi River system, 1940-2007. Hydrological Processes. 24(1), 35-49.

Milliman, J. D. \& Syvitski, J. P. (1992) Geomorphic/tectonic control of sediment discharge to the ocean: the importance of small mountainous rivers. The Journal of Geology. 100, 525-544.

Morton, R. A., et al. (2010) Quantifying large-scale historical formation of accomodation in the Mississippi Delta. Earth Surface Process and Landforms. 35(14), 1625-1641.

Stanley, D. J. \& Warne, A. G. (1994) Worldwide initiation of Holocene marine deltas by deceleration of sea-level rise. Science. 265(5169), 228-231.

USACE (2014) New Orleans District, Beneficial use of dredged material. US Army Corps of Engineers. Available from: http://www.mvn.usace.army.mil/About/Offices/Operations/BeneficialUseofDredgedMaterial.aspx (March 1, 2014)

USEPA (2007) The role of the federal standard in the beneficial use of dredged material from U.S. Army Corps of Engineers new and maintenance navigation projects. Oceans and Coastal Protection Division, Office of Wetlands, Oceans, and Watersheds, Office of Water, U.S. Environmental Protection Agency. EPA842-B-07-002.

Zalasiewicz, J., et al. (2010) The new world of the Anthropocene 1. Environmental Science \& Technology. 44(7), $2228-2231$. 